\title{
Effect of different rearing condition on early age in the maze, open-field, and aversive behaviours in the dairy cow during the first lactation
}

\author{
Jan Broucek $^{a *}$ (D) | Michal Uhrincat ${ }^{a}$ (i) | Peter Kisac ${ }^{a}$ Anton Hanus ${ }^{a}$
}

National Agricultural and Food Centre, Research Institute of Animal Production Nitra, Hlohovecka 2, 95141 Luzianky, Slovakia

*Corresponding author: jan.broucek@nppc.sk; jbroucek@hotmail.com

\begin{abstract}
The aim of the study was to tested hypotheses that the primiparous cow's behaviour is impacted by the method of rearing from the second day of life to weaning. 53 Holstein primiparous cows were used. They were reared in different ways during milk nutrition. Calf-heifers were assigned to one of five rearing groups on the second day after having nursed their mothers for 24 hours: $H$ ) hutch; $H A$ ) hutch, from 7 days pen with an automated drinking machine (ADM); MA) with mother, from 7 days pen with an $A D M ; M H)$ with mother, from 7 days hutch; $M N$ ) with mother, from 4 days with nursing cows. After weaning ( 56 days), all heifers were kept in group pens, after calving in free-stall housing. Maze learning ability was tested in the third month of lactation. In the 5th month, cows were observed in the open-field, in the seventh month they were subjected to an aversion test (AT). Group MN was the slowest in solving all tasks and HA the fastest. Differences were recorded among groups in the first-day evaluation $(P<0.01)$. No differences in open field tests were found. In the AT traversing, the slowest were groups $\mathrm{H}$ and $\mathrm{HA}$, the fastest $\mathrm{MH}$ and MA $(P<0.01)$. The time of the first return was different $(P<0.001)$. On the first day, the most vocalized cows of the MN group $(P<0.05)$. The results show that the method used to rear heifers may have a significant impact on their maze and aversive behaviour.
\end{abstract}

Keywords dairy cattle, ethological test, weaning

\section{Introduction}

The concern for the welfare of animals developed the necessity for behaviour activity measuring. Farm animals, including dairy cattle, are strongly motivated to explore and investigate when they encounter a new environment, such as changes in drinker or feeder location, regrouping, new milking procedures, handling and restraint techniques (halters, squeeze chutes), various standard agricultural practices as dehorning, drenching, hoof trimming, loading and transporting, computer/controlled system (Fraser and Broom 1997; Albright and Arave 1997; Costa et al 2016; Novak et al 2019).

Various ethological methods are used for an assessment of environmental changes. Kilgour (1981), Stewart et al (1992) and Arave et al (1992a) recommended the closed-field maze test as an appropriate apparatus for the testing of the learning ability of dairy cows. The open-field test is used for the analysis of emotional activity. This method is suitable also for evaluation of the effect of different environment and housing during the rearing (Arave et al 1985). The individual introduction of the animal to a nonfamiliar environment can induce fear and exploratory motivations (Bouissou and Boissy 1988; Houpt 1991; Boissy and Bouissou 1995; Jensen et al 1997). Stay in the open-field arena reflects several motivations: sniffing, defecation, vocalization, and walking (Passillé de et al 1995; Lauber et al 2009; MacKay et al 2014).

Handling tests were designed to evaluate differences between animals in their behavioural reactions to humans. Farm animals are often subjected to aversive handling, which can result in them becoming fearful of the person handling them (Rushen 1986; Boivin et al 1992; Pajor et al 2000; Hemsworth 2003; Mogensen et al 2010). This aversion can worsen handling problems, increase the likelihood of injuries to both animals and handlers, and reduce animal welfare and productivity (Hemsworth and Barnett 1987; Blackshow 1996; Pajor et al 2003; Grandin 2019). In contrast, gentle handling can reduce animals' fear of people (Jago et al 1999).

The aim of the study was to tested hypotheses that the primiparous cow's behaviour is impacted by the method of rearing from the second day of life to weaning.

\section{Materials and Methods}

\subsection{Animals, treatments and housing}

The treatment of the animals was approved by the Ministry of Agriculture and Rural Development of the Slovak Republic, no. 115/1995 Z.z. and 377/2012 Z.z. The experiments were carried out in accordance with the Code of Ethics of the EU Directive 2010/63/EU for animal experiments and were performed according to the ethical guidelines and regulations set forth by National Agricultural and Food 
Centre, Research Institute for Animal Production Nitra/Ethical Commission, Hlohovecka 2, Luzianky, Slovakia.

The study was performed in Nitra, Slovakia (48 $32^{\prime} \mathrm{N}$, $18^{\circ} 03^{\prime} \mathrm{E}$, altitude $144 \mathrm{~m}$ above sea), 53 Holstein primiparous cows were used. They were randomly assigned into five groups equally on the second day after birth:

$\mathrm{H}(\mathrm{N}=9)-24$ hours in individual maternity pen with mother, then in individual hutch until weaning; $\mathrm{HA}(\mathrm{N}=10)$ after 24 hours in individual maternity pen with mother in individual hutch from 2 nd to 7 th day, then in loose housing of the calf barn with automated drinking machine (ADM) until weaning; $M A(N=9)$ - individual maternity pen with mother until the 7th day, then in calf barn with ADM until weaning; $\mathrm{MH}(\mathrm{N}=10)$ - individual maternity pen with mother until the 7th day, then in individual hutch until weaning; $\mathrm{MN}(\mathrm{N}=13)$ in the individual maternity pen with mother until the 4th day, then penned with nursing cows until weaning.

The individual maternity pen (size $4.5 \times 4.5 \mathrm{~m}$ ) was used also for $\mathrm{MA}, \mathrm{MH}$, and $\mathrm{MN}$ groups to the heifer calves age of 7 days. A small part of the pen was separated for calf $(1.2 \times 4.5)$. Mothers were milked twice a day from the second to the seventh day.

Hutches were made from fibre-glass $(1.8 \times 1.2 \mathrm{~m})$ had an outside fenced yard $(1.8 \times 1.2 \mathrm{~m})$. Each pen of HA and MA groups ( $9 \times 4.5 \mathrm{~m}, 10-15$ calves, from $7^{\text {th }}$ day) had one milk feeder equipped with one teat.

Pen for nursing cows with calves (group MN) was of $9 \times 4.5 \mathrm{~m}$ ( 3 nursing cows and 10-12 calves). Cows were tied in the pen, calves lose.

All heifers were weaned from the milk liquid nutrition at the age of eight weeks. After weaning, they were housed in age-balanced group pens with bedding. Approximately 10 - 15 calves were kept in a pen of 9x4.5 m. Heifers have been housed in loose housing pens since the age of 6 months (18x4.5 m, 15-20 heifers in the pen). They were calved in the individual maternity pens, then were housed in a free-stall barn from 5th day of lactation. Each treatment group had a pen.

\subsection{Feeding}

All calves received colostrum of own mother for the first 24 hours by suckling ad libitum.

Heifer calves of $\mathrm{H}$ group received colostrum and mothers milk ad libitum three times a day from a bucket with nipple from the second to fourth day. After three days, when they were made to drink milk replacer (MR), they received from the eighth day $6 \mathrm{~kg}$ of MR per day from a bucket with nipple divided into 2 portions into $12 \mathrm{~h}$ intervals.

Heifer calves of HA group received colostrum and mothers milk three times a day from a bucket with nipple from the second to fourth day. After three days, when they were made to drink a MR, they received from the eighth day $6 \mathrm{~kg}$ of MR per day from an ADM divided into 4 portions into $6 \mathrm{~h}$ intervals.

Heifer calves of MA group suckled colostrum and mothers milk ( $3 \times 10$ minutes/day) from the second to the seventh day. After three days, when they were made to drink
$\mathrm{MR}$, calves received $6 \mathrm{~kg}$ of MR per day from an ADM divided into 4 portions into $6 \mathrm{~h}$ intervals.

Heifer calves of $\mathrm{MH}$ group suckled colostrum and mothers milk ad libitum ( $3 \times 10$ minutes/day) from the second to the seventh day. After three days, when they were made to drink MR, they received $6 \mathrm{~kg}$ of MR per day from a bucket with nipple divided into 2 portions into $12 \mathrm{~h}$ intervals.

Heifer calves of MN group suckled colostrum and mothers milk ad libitum three times a day $(3 \times 10$ minutes/day) from the second to the third day. They suckled milk of nursing cows from 4th day (suckle at any time).

Suckling time a mother's udder (3x10 minutes) was determined during preparation on experiment according to (Passillé de, Rushen, 2006). We needed to know how much milk will be available to the calf during suckling. The calves were weighed immediately before and after each suckling to assess milk intake. For $3 \times 10$ minutes, the calf should receive $6 \mathrm{~kg}$ of milk from the average herd cow. The number of MN heifer calves per nursing cow was determined according to milk yield of selected cows so that $6 \mathrm{~kg}$ of milk/calf daily should be available.

The calves could eat starter mixtures and alfalfa hay in free choice until weaning. They received $1,5 \mathrm{~kg}$ of concentrate mixture (CM) per day and alfalfa hay offered free choice from weaning to 180 days. From the age of 90 days they fed also corn silage.

From the 181st day, all heifers were fed the same diet according to Slovakian recommendations for intake of dry matter to attain $0.75 \mathrm{~kg}$ average daily gain. The total mixed ration (TMR) contained alfalfa hay, corn silage, CM, and mineral/vitamins supplements. Water was provided for $a d$ libitum intake at all times.

The cows of all treatment groups were fed the TMR consisting of corn silage, alfalfa haylage, alfalfa hay, barley straw, sugar-beet pulp, brewer's grain, and CM. The TMR was administered to troughs by a feeding wagon. Cows did not receive $\mathrm{CM}$ separately. Feeding was allowed throughout the $24 \mathrm{~h}$ period. Automatic watering troughs were located next to feed bunks. The total mixed ration was calculated according to Slovakian nutrient requirements of dairy cattle (Petrikovic and Sommer 2002). Equal conditions of nutrition were ensured in all groups.

The methods of Slavik et al (2009) and Novak et al (2010) for the health evaluation were used. Live body weight was recorded every month during lactation.

\subsection{Trial 1-Closed field maze tests}

The learning ability (Hebb-Williams closed field maze test) was evaluated in the third month of the first lactation. The experimental facility was constructed in an $8 \times 14 \mathrm{~m}$ indoor room with concrete floor and height of $6.2 \mathrm{~m}$. The floor was marked into 32 rectangles. The starting box $(2.5 \times 3$ $\mathrm{m}$ ) was located in the left corner of the maze and the goal place in the right corner of the opposite side of the maze facility. The room was equipped with a three video cameras with built-in microphones that were mounted under the ceiling, above the starting box, the maze unit segments and 
the goal place, so that the whole area of the maze was visible. The cameras were connected to a video recorder and monitor in a laboratory room. The concrete floor was carefully cleaned by flushing of water before each cow testing.

Problem tasks (maze unit segments) were constructed from $2 \mathrm{~m}$ high walls created from recycled Tetra pack carton panels (hardened and pressed paper, $2 \mathrm{~cm}$ thick, polyethylene and aluminium foil, fixed in steel frames). Cows solved six tasks during three consecutive days (Figure 1). Tasks 1 and 2 required a left side solution, tasks 3 and 4 a right-side solution, and 5 and 6 a central solution (Kilgour 1981). Odd-numbered tasks had a visual form while evennumbered tasks were non-visual. Each task was performed twice (four runs per day) and cows were observed in a random order in each task. On the first observation day the calves completed five runs, the first run was for training.

The dairy cow was released from start box into the maze and a manually controlled gate, made of metal bars covered with sheet metal so that the cow cannot see back, were closed behind it. If the cow stood without movement in the enter part or other parts of the maze apparatus for more than 3 minutes, it was forced gently to movement. When the cow stood without movement more than 3 minutes in the rear part of the maze, it was also taken out through goal box.

The motivation to finish the problem was access to a $0.5 \mathrm{~kg} \mathrm{CM}$ at the exit. The manger was positioned so that it was visible from the rear part. The cow was allowed to eating for only a few seconds, whereupon it was lead out of the maze.

The speed of traversing the maze (running time), the time of standing in the maze, and exploration were recorded. Exploration was defined as any contact of the muzzle with wall or floor. Learning speed was assessed using the time until the cow achieved the goal.

\subsection{Trial 2-Open-field tests}

Dairy cows were individually tested in the 5 th month of lactation in a $10 \times 10 \mathrm{~m}$ indoor arena with height $3.9 \mathrm{~m}$. Cows were subjected to four tests during 2 consecutive days. The trial tests were 5 minutes long and repeated twice a day during 2 consecutive days. Arena had a concrete floor and was divided by white lines into 9 equal squares. The facility was visually and acoustically isolated from other animals. Only one door and an observation window from the next Ethology Laboratory led to the room. Sound speakers were placed above the cow head at a high of $3.2 \mathrm{~m}$. The arena was equipped with two video cameras which were placed under the ceiling in opposite corners of the room to display the entire monitored space. All recording equipment was connected to a video recorder and monitor in a laboratory room.

After testing of each cow, the excrements were removed and the concrete floor of the arena was carefully cleaned by flushing with water. A manger containing $0.5 \mathrm{~kg}$ of $\mathrm{CM}$ (always fresh portion) was placed by the wall in square 8 during all tests. Noise ( $80 \mathrm{~dB}$ and $8 \mathrm{kHz}$ ) was used as a stress factor in the first two tests. There was no noise during the third test, the cows were exposed to isolation and silence. At the 4th test, animal-human interactions were studied. An unfamiliar man in white coverall was seated by the wall in square 4 (Figure 2).

Activities to be recorded during the tests were include: the number of grid crossings (also called crossed squares), starting and stopping the eating of $\mathrm{CM}$; the number of meals taken; the number of sniffing the ground, walls, window, and door; and the number of vocalizations, defecations, and urinations. Response to human was assessed during the last test as latency to approach the unfamiliar person (staying in square 4). We recorded whether the cow made contact with the human object (sniffing or licking), along with the number of retreats (stepping away while oriented to the man) or startle responses (a sudden movement of the head or body without taking a step).

\subsection{Trial 3-Aversive tests}

The behaviour of dairy cows was observed in an aversion test (AT) for three consecutive days (12 runs). The barriers and the wall of the building were painted grey. The AT, using $2 \mathrm{~m}$ high barriers from the left side and building a wall from the right side, was divided into 3 parts, A-starting place (3.72 $\mathrm{m}$ width, $2.4 \mathrm{~m}$ length), B-corridor, C-handling place (3.36 $\mathrm{m}$ width, $5.5 \mathrm{~m}$ length), and F-exit. The starting place (A) was separated from the corridor (B) by a manually controlled gate made of metal bars covered with a sheet of metal painted grey so that the cow cannot see back (Figure 3).

The corridor ( $B$ ) was $16.1 \mathrm{~m}$ long and $1.86 \mathrm{~m}$ wide, divided into 7 sections $(2.3 \times 1.86 \mathrm{~m})$. In part $\mathrm{C}$, a pleasant and aversive treatment was applied. The manger with $0.5 \mathrm{~kg}$ of concentrate mixture, visible from the starting place, was located just to the right at the exit of the corridor. The cow couldn't eat a whole dose of food, just taste it. The feed intake time was only $15 \mathrm{~s}$. If the cow did not come out voluntarily, she was forced to do so in a mild manner. The manger with food was available to the cows during all runs.

The AT was equipped with three video cameras which were mounted under the ceiling directly above the starting place $(A)$, the corridor $(B)$, and the handling place $(C)$. These cameras were connected to a video recorder and monitor in a laboratory room. Feces were removed and the concrete floor of starting box, corridor, and handling place was pressure washed before each cow testing.

The gate opened so the cow could enter the corridor voluntarily. If the cow did not go voluntarily, a handler (man, familiar for cows) entered to the corridor behind her. He pushed her slightly from behind (gently from the back), so he guided her through the entire corridor.

If the heifer stood motionless in some corridor section for longer than 3 minutes, a handler entered into the corridor and gently encouraged (pushed) the cow to move. The cow was indicated as driven. If the cow stood motionless for more than 3 minutes in the rear part of the corridor (C), it was forced out of the AT. 
On the first day a manipulator (unfamiliar man, standing at the handling place) brushed the cows (maximally 12-times per cow) during all four runs; this was considered as a positive treatment. The second and third day the animals received negative treatments from the manipulator. At the second day, auditory signal (air horn noise, $128 \mathrm{~dB}$ for the length of $1 \mathrm{~s}$ ) acted on the dairy cows in the first three runs from a distance of $1 \mathrm{~m}$. The third day was applied to the dairy cows a single electrical shock of $1.5 \mathrm{kV}$ in the length of $1 \mathrm{~s}$ by treated stick during the first two runs.
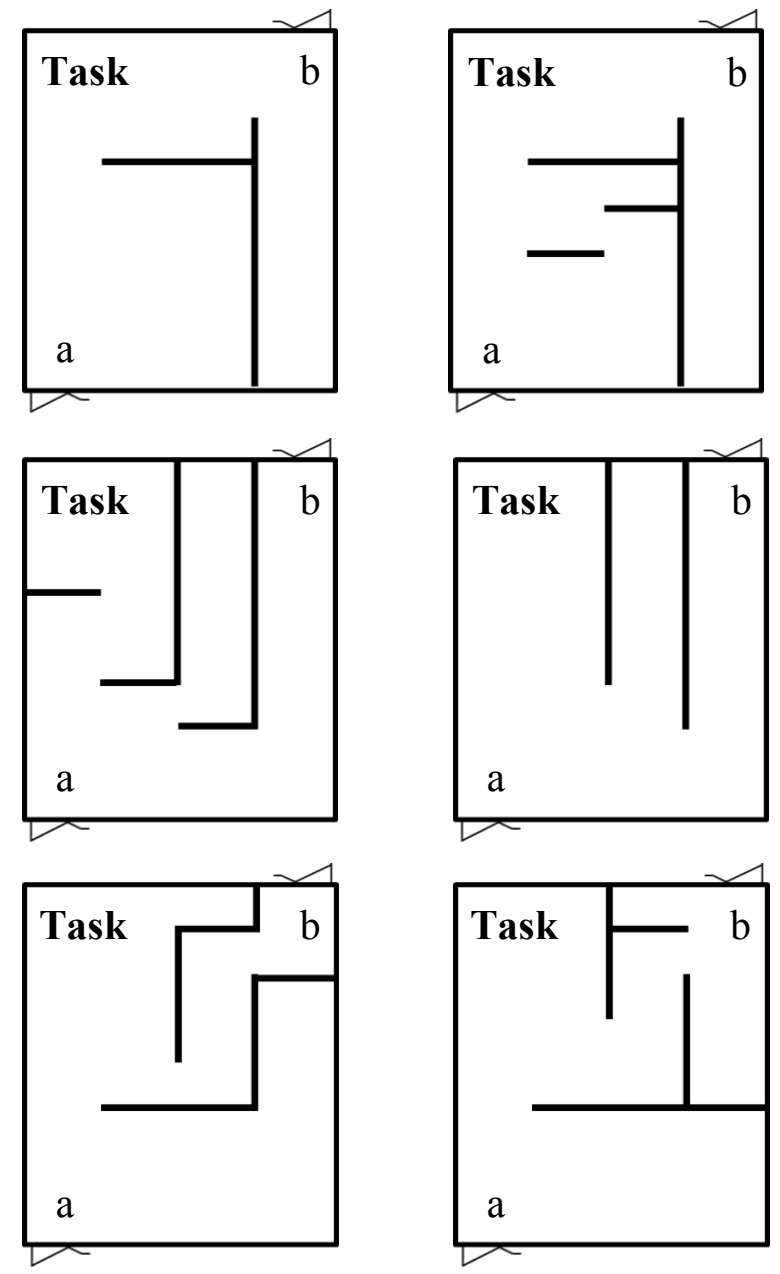

Figure 1 Closed field maze facility. $a=$ start,$b=$ exit

Test 1 - 3

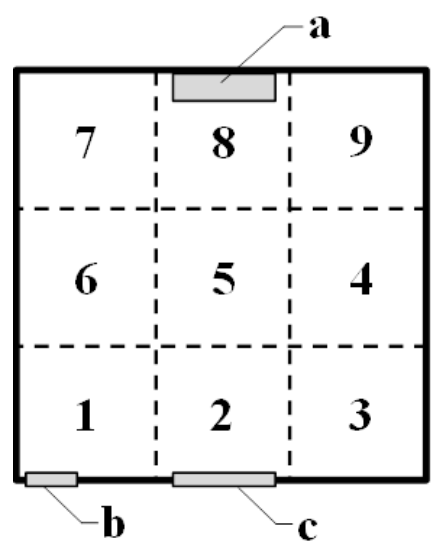

Test 4

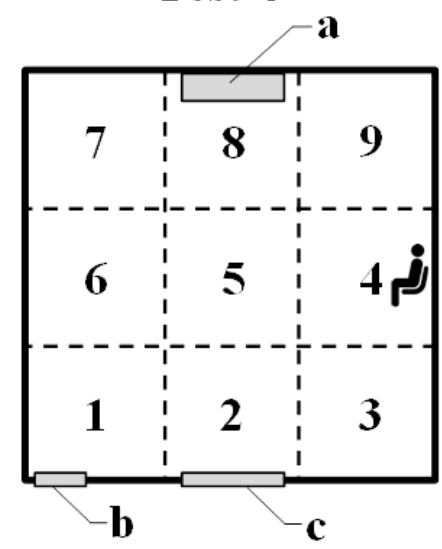

Figure 2 Open field tests.

$\mathrm{a}=$ manger, $\mathrm{b}=$ entrance door, $\mathrm{c}=$ observation window 
There were observed time to cross the corridor to exit, time spent standing in the last (7th) section, number of returns, enabling the brushing of the manipulator, reaction after leaving TAA, number of cows feeding after leaving the corridor (B), number of sections, in which animals stood more than three seconds, and frequency of vocalizations.

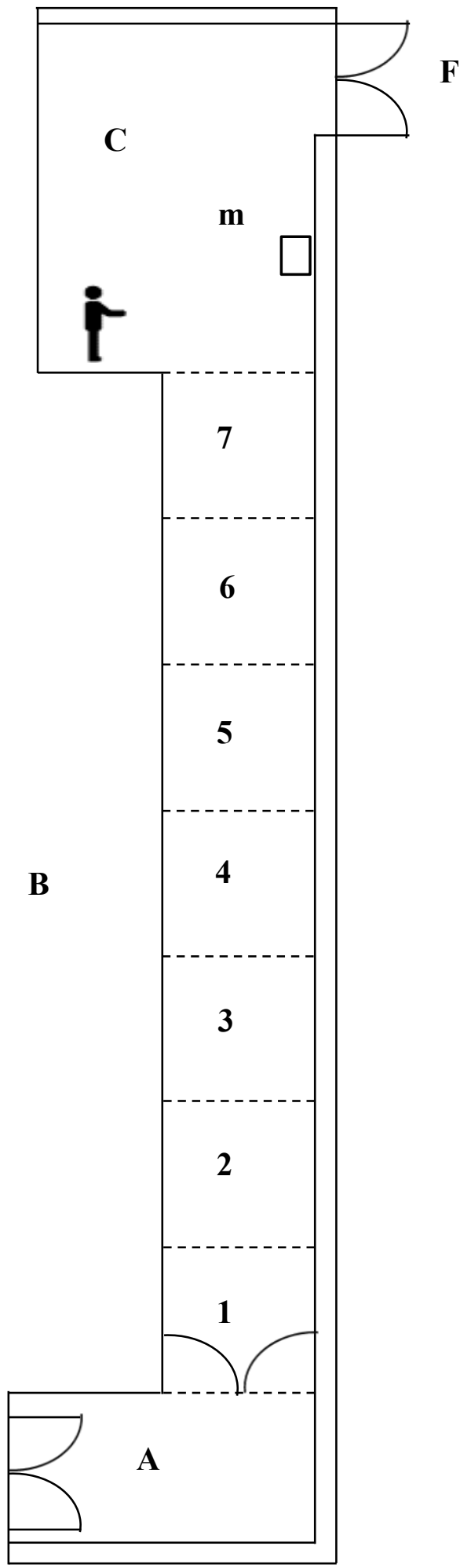

Figure 3 Aversive test facility (AT). A = starting place, $\mathrm{B}=$ corridor; $\mathrm{C}=$ handling place; $\mathrm{F}=$ exit; $\mathrm{m}=$ manger.
During handling and subsequent leaving of the AT, the reaction of the cows was evaluated by a three-point system ( 1 point $=$ docile, 2 points $=$ restless, 3 points $=$ nervous $)$. The difficulty in getting the cow onto the handling place was scored as 1 (voluntarily), 2 (some pushing required), 3 (one person pushing with maximum force), or 4 (two people required).

\subsection{Behavioural data acquisition and processing}

Behavioural data of all three ethological trials were obtained by video observations and electronic measurements. The rooms of the maze, arena for open-field tests, and treatment aversion alley were equipped with video cameras for continuous filming of the cows' activities. The computer technics (cameras Samsung SCB-3000P, HDD Digital Versatile Recorder H.264 DVR), and the timeline behaviour coding software (Observer XT, Noldus) were used.

\subsection{Statistical calculations}

The data were analysed using a general linear model ANOVA (AOV/AOCV) by the statistical package STATISTIX, Version 10.0. The dependent variables were times maze traversing and standing, number of square crossings, vocalizations, and defecations. The independent variable was treatment group.

Differences between groups were tested by Comparisons of Mean Ranks. Significant differences among means were tested by Bonferroni's test. All values are reported as means \pm standard deviation. The following model of General AOV/AOCV on the observed factor (treatment) was used:

$$
Y i j k=\mu+T i+\varepsilon i
$$

where $Y i$ is a dependent variable, $\mu$ is the overall mean, $T i$ is the effect of the factor treatment group on the level $i$, and $\varepsilon i$ is the residual error.

The behaviour was analysed directly from a monitor screen and checked up from video tape afterwards.

\section{Results}

\subsection{Trial 1}

Group MN was the slowest in solving all tasks and $\mathrm{HA}$ the fastest $(H$ 1832.2 $\pm 786.1 \mathrm{~s}, \mathrm{HA} 1135.5 \pm 855.5 \mathrm{~s}, \mathrm{MA}$ $1338.6 \pm 943.2 \mathrm{~s}, \mathrm{MH} 1290.9 \pm 667.6 \mathrm{~s}, \mathrm{MN} 2051.3 \pm 1015.1 \mathrm{~s}, P$ $>0.05$ ) (Table 1). In the evaluation of individual tasks, $\mathrm{MH}$ cows were the fastest in the first four and MA cows in the fifth and sixth learning tasks.

Significant differences were recorded between the $\mathrm{MN}$ and $\mathrm{MH}$ groups in the first-day evaluation $(\mathrm{H} 484.0 \pm 315.5$

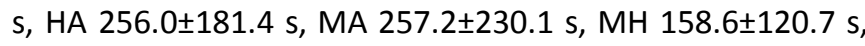
MN 546.1 \pm 367.6 s) (Table 1). At the first day, significant differences were observed in the first $(H 230.3 \pm 143.9 \mathrm{~s}, \mathrm{HA}$ $159.0 \pm 140.9$ s, MA $97.7 \pm 83.8$ s, MH $82.4 \pm 67.0$ s, MN $245.5 \pm 142.7 \mathrm{~s}, P<0.01)$ and in second tasks $(H 253.7 \pm 191.1$ s, HA $96.0 \pm 101.2 \mathrm{~s}, \mathrm{MA} 159.6 \pm 212.4 \mathrm{~s}, \mathrm{MH} 76.3 \pm 76.7 \mathrm{~s}, \mathrm{MN}$ $300.6 \pm 262.9 \mathrm{~s}, P<0.05)$ 
No significant differences were found between the groups in the time of standing in the maze or the length and number of explorations. The $\mathrm{MN}$ cows spent more time standing than the others $(P>0.05)$.

Table 1 Maze and open-field behaviour.

\begin{tabular}{|c|c|c|c|c|c|c|c|}
\hline \multirow[t]{2}{*}{ Group N } & & Mean SD & & Significance & Mean SD & & Significance \\
\hline & \multicolumn{3}{|c|}{ Time of maze traversing } & \multicolumn{4}{|c|}{ Number of grid crossings } \\
\hline \multicolumn{8}{|l|}{ Day 1} \\
\hline $\mathrm{H}$ & 9 & 484.0 & 315.5 & $0.0038 * *$ & 66.4 & 21.7 & NS \\
\hline $\mathrm{HA}$ & 10 & 256.0 & 181.4 & $\mathrm{MN}: \mathrm{MH}^{* *}$ & 58.7 & 15.6 & \\
\hline MA & 9 & 257.2 & 230.1 & & 57.2 & 17.8 & \\
\hline $\mathrm{MH}$ & 11 & 158.6 & 120.7 & & 52.1 & 7.6 & \\
\hline $\mathrm{MN}$ & 14 & 546.1 & 367.6 & & 71.2 & 23.9 & \\
\hline \multicolumn{8}{|l|}{ Day 2} \\
\hline $\mathrm{H}$ & 9 & 689.8 & 388.4 & & 101.7 & 34.1 & NS \\
\hline HA & 10 & 545.5 & 403.8 & & 102.2 & 30.3 & \\
\hline MA & 9 & 688.7 & 459.2 & & 100.7 & 26.6 & \\
\hline $\mathrm{MH}$ & 11 & 614.1 & 372.0 & & 108.2 & 44.0 & \\
\hline $\mathrm{MN}$ & 14 & 740.6 & 463.4 & & 89.8 & 37.7 & \\
\hline \multicolumn{8}{|l|}{ Day 3} \\
\hline $\mathrm{H}$ & 9 & 658.7 & 388.5 & NS & & & \\
\hline $\mathrm{HA}$ & 10 & 335.0 & 375.0 & & & & \\
\hline $\mathrm{MA}$ & 9 & 392.7 & 329.6 & & & & \\
\hline $\mathrm{MH}$ & 11 & 518.2 & 330.6 & & & & \\
\hline $\mathrm{MN}$ & 14 & 685.1 & 427.7 & & & & \\
\hline \multicolumn{8}{|c|}{ Total for all days } \\
\hline $\mathrm{H}$ & 9 & 1833.2 & 786.1 & NS & 168.1 & 47.7 & NS \\
\hline $\mathrm{HA}$ & 10 & 1135.5 & 855.5 & & 158.9 & 28.2 & \\
\hline $\mathrm{MA}$ & 9 & 1338.6 & 943.2 & & 157.9 & 33.8 & \\
\hline $\mathrm{MH}$ & 11 & 1290.9 & 667.6 & & 160.3 & 43.6 & \\
\hline $\mathrm{MN}$ & 14 & 2051.3 & 1015.1 & & 161.0 & 55.4 & \\
\hline
\end{tabular}

${ }^{* *} \mathrm{P}<0.01 ; \mathrm{H}=$ hutch until weaning; HA hutch to 7th day, then with ADM until weaning; MA with mother until the 7th day, then with ADM until weaning; $\mathrm{MH}$ with mother until the 7th day, then hutch until weaning; MN with mother until the 4th day, then with nursing cows until weaning; $\mathrm{N}=$ number of animals; $\mathrm{SD}=$ standard deviation; $\mathrm{NS}=$ non-significant.

\subsection{Trial 2}

No significant differences among the treatment groups in each open field test were found for observed activities. The difference compared to the square crossings were not significant even in the 1st minute of the 1st test $(\mathrm{H}$ 33.4 \pm 11.3 , HA $34.6 \pm 16.1 \mathrm{~s}$, MA $29.8 \pm 12.5 \mathrm{~s}, \mathrm{MH} 27.4 \pm 7.7 \mathrm{~s}$, MN 39.7 $\pm 21.7 \mathrm{~s}, P>0.05)$. The tendency of most to move as measured by the number of crossed squares for all tests showed cows of group $\mathrm{H}(168.1 \pm 47.7)$, the lowest movement

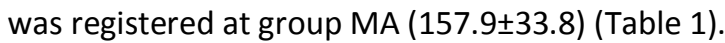

There were no differences among groups in feeding behaviour (length eating, number of meals taken), sniffing (ground, walls, window, and door), number of vocalizations, defecations, and urinations, or relationship to unknown man (staying in square 4, sniffing, licking of man, number of retreats or startle responses). Contact behaviours to the unfamiliar person (especially frequencies or lengths of staying in the square) were tended to be highest in $\mathrm{H}$ and $\mathrm{MH}$ groups and the lowest in $\mathrm{MN}(P>0.05)$.

\subsection{Trial 3}

In the AT traversing for the whole experiment, the slowest were group $\mathrm{H}$ and $\mathrm{HA}(275.6 \pm 77.7 \mathrm{~s}, 227.9 \pm 122.8 \mathrm{~s})$ and the fastest $\mathrm{MH}$ and $\mathrm{MA}(114.8 \pm 62.8$ and $122.9 \pm 115.2 \mathrm{~s})$, the differences were statistically significant $(P<0.01)$. On the first-day, we did not find out any significant differences between groups. After negative treatment on the second day the animals of group $H(104.3 \pm 42.7)$ needed a longer time to across the alley than animals of groups $\mathrm{MH}$ and $\mathrm{MA}$ (34.1 $\pm 23.5 \mathrm{~s}, 39.7 \pm 55.4 \mathrm{~s}, P<0.01)$. On the third day, the results were similar $(\mathrm{H} 140.8 \pm 49.5 \mathrm{~s}$, HA $126.9 \pm 61.0 \mathrm{~s}, \mathrm{MA}$ $66.5 \pm 63.6 \mathrm{~s}, \mathrm{MH} 59.2 \pm 45.1 \mathrm{~s}, \mathrm{MN} 90.8 \pm 69.8 \mathrm{~s}, P<0.05$ ) (Table 2).

Rearing treatment did not affect the number of sections, in which the animals stood more than three seconds, or the time of standing in the last, seventh section. Cows of $\mathrm{H}$ group stood the longest time in the 7 th section (42.3 s), the shortest time was recorded for the whole trial in the MA and $\mathrm{MH}$ groups (24 s and $26.4 \mathrm{~s}$ ).

On the first day, the cows did not return towards the start (they did not turn). No significant differences were found between the groups in the number of returns even on the second day, although the animals returned the most in 
groups $\mathrm{HA}$ and $\mathrm{H}(1.2 \pm 1.6,1.2 \pm 0.8)$. A significant difference ( $P$ $<0.05)$ was not recorded until the third day. Groups HA (2.4 \pm 2.4$)$ and $\mathrm{MN}(0.4 \pm 0.8)$ were statistically different.

At the time of the first return, we found significant differences between the groups on the second and third days $(P<0.01)$ (Table 2). The cows of $\mathrm{MA}, \mathrm{MH}$, and $\mathrm{MN}$ groups returned the fastest. Differences between treatment groups were also significant for the overall assessment of all three days $(\mathrm{H} 46.0 \pm 39.5 \mathrm{~s}, \mathrm{HA} 35.9 \pm 27.4 \mathrm{~s}, \mathrm{MA} 6.1 \pm 15.6 \mathrm{~s}, \mathrm{MH}$ $7.5 \pm 8.5 \mathrm{~s}, \mathrm{MN} 11.1 \pm 11.3 \mathrm{~s}, P<0.001)$.

No significant difference was found in the number of brushings performed by the manipulator in any of the tests. The animals of the $\mathrm{MH}$ group were brushed the most (19.1 times) and the cows of the MN group the least ( 8.8 times).

In the evaluation of reaction after leaving TAA, we did not find any differences between the groups on a single day. Observed treatment groups did not differ even in the average for three days (H 1.4 $\pm 0.1, \mathrm{HA} 1.4 \pm 0.2, \mathrm{MA} 1.6 \pm 0.3, \mathrm{MH}$ 1.4 $\pm 0.3, \mathrm{MN} 1.5 \pm 0.2, P>0.05)$.

At the first day, the most vocalized cows of MN group, group comparison was statistically different $(\mathrm{H} 3.6 \pm 2.8, \mathrm{HA}$ 2.0 $\pm 2.8, \mathrm{MA} 1.2 \pm 2.4, \mathrm{MH} 1.2 \pm 2.4, \mathrm{MN} 5.2 \pm 4.4, P<0.05)$. During the second and third day, no significant differences among treatment groups were found in the frequency of vocalization.

\section{Discussion}

All trials are based on five different rearing types. They deal with current issues. For modern technological systems, the animals needed are teachable, adaptable, tolerant with good orientation. They must be able to adapt quickly to changes in the environment. Possible differences between cow groups can be explained by the conditions of their period of milk liquid feeding (rearing system, handling, fear, time of weaning from mother, and early experience).

Table 2 Aversive behaviour.

\begin{tabular}{|c|c|c|c|c|c|c|c|}
\hline \multirow[t]{2}{*}{ Group N } & & Mean SD & & Significance & $\overline{\text { Mean SD }}$ & & Significance \\
\hline & & \multicolumn{3}{|c|}{ Time of corridor traversing (s) } & \multicolumn{3}{|c|}{ Time of the first returning (s) } \\
\hline \multicolumn{8}{|l|}{ Day 1} \\
\hline $\mathrm{H}$ & 9 & 30.5 & 23.6 & & 0.0 & 0.0 & \\
\hline $\mathrm{HA}$ & 10 & 30.2 & 29.8 & & 0.8 & 2.7 & \\
\hline MA & 9 & 16.7 & 7.6 & NS & 0.0 & 0.0 & NS \\
\hline $\mathrm{MH}$ & 10 & 21.5 & 17.4 & & 0.0 & 0.0 & \\
\hline $\mathrm{MN}$ & 13 & 31.8 & 38.9 & & 1.8 & 4.0 & \\
\hline \multicolumn{8}{|l|}{ Day 2} \\
\hline $\mathrm{H}$ & 9 & 104.3 & 42.7 & $0.0110 *$ & 9.8 & 8.5 & $0.0046 * *$ \\
\hline $\mathrm{HA}$ & 10 & 70.7 & 47.6 & $\mathrm{H}: \mathrm{MH}, \mathrm{MA}^{*}$ & 17.3 & 19.9 & $\mathrm{H}: \mathrm{MN}, \mathrm{MH}, \mathrm{MA}^{*}$ \\
\hline MA & 9 & 39.7 & 55.4 & & 0.0 & 0.0 & \\
\hline $\mathrm{MH}$ & 10 & 34.1 & 23.5 & & 3.3 & 4.9 & \\
\hline $\mathrm{MN}$ & 13 & 55.8 & 47.6 & & 4.4 & 6.1 & \\
\hline \multicolumn{8}{|l|}{ Day 3} \\
\hline $\mathrm{H}$ & 9 & 140.8 & 49.5 & $0.0142^{*}$ & 28.7 & 26.3 & $0.0016 * *$ \\
\hline $\mathrm{HA}$ & 10 & 126.9 & 61.0 & $\mathrm{H}: \mathrm{MH}^{*}$ & 25.3 & 22.9 & $\mathrm{H}: \mathrm{MN}, \mathrm{MH}, \mathrm{MA}^{*}$ \\
\hline MA & 9 & 66.5 & 63.6 & & 5.1 & 14.7 & \\
\hline $\mathrm{MH}$ & 10 & 59.2 & 45.1 & & 4.3 & 7.3 & \\
\hline $\mathrm{MN}$ & 13 & 90.8 & 69.8 & & 4.9 & 7.3 & \\
\hline \multicolumn{8}{|c|}{ Total for all days } \\
\hline $\mathrm{H}$ & 9 & 275.6 & 77.7 & $0.0081^{* *}$ & 46.0 & 39.5 & $0.0003 * * *$ \\
\hline $\mathrm{HA}$ & 10 & 227.9 & 122.8 & $\mathrm{H}: \mathrm{MH}, \mathrm{MA}^{*}$ & 35.9 & 27.4 & $\mathrm{H}: \mathrm{MN}, \mathrm{MH}, \mathrm{MA}^{* *}$ \\
\hline $\mathrm{MA}$ & 9 & 122.9 & 115.2 & & 5.1 & 14.7 & HA:MA* \\
\hline $\mathrm{MH}$ & 10 & 114.8 & 62.8 & & 7.5 & 8.5 & \\
\hline $\mathrm{MN}$ & 13 & 178.4 & 126.9 & & 11.1 & 11.3 & \\
\hline
\end{tabular}

\subsection{Trial 1}

At the experiment, it was found that the fastest learning was in the group $\mathrm{HA}$ and the worst learning in the $M N$ group. Animals reared without mother and from the seventh day of life by the ADM (HA) were probable better adaptable on new and novel environments than animals reared with mother to the fourth day and to weaning at the age of 56 days by nursing cows (MN). According to authors (Kilgour et al 1991; Arave et al 1992a; Veissier 1993), the method of rearing can affect the maze learning of cattle.

It seems that animals kept for a long time only with a nursing cow are non-independent and they are not able to quickly adapt. It was proved also in our previous experiment focused on maze behaviour of calf-heifers (Broucek et al 
2002). However, the term lack of independence is closely connected with fear (Hart 1985; Grandin 2019).

According to findings of Veissier et al (1998), this could be caused also by the effect of weaning from adoptive mother. It may have been a violent break of the close cowcalf bond at the 56th day. In our opinion, the worse orientation and slower learning in the maze of cows MN group were caused by the lack of handling, which had a significant impact only in the group from hutches $(H)$, and an impossibility of instrumental learning, which was the most expressively pronounced in the group from ADM (HA).

Many authors have studied the effect of early rearing experience on learning behaviour. Animals may be excessively fearful as a function of prenatal stress or maternal deprivation (Houpt 1991; Arave 1996; Fraser and Broom 1997; Jones 1997; Mala et al 2019). The early handling experience affected learning ability (Boissy and Le Neindre 1990).

Purcell and Arave (1991) found that calves reared in social isolation (individual hutches) reached the goal in a maze significantly sooner than calves reared in groups. It may be a consequence of the animals coping better with human handling and separation from herdmates (Albright and Arave 1997). Also Arave et al (1992a; 1992b) found that preweaning isolation affected learning ability in calves and adult dairy cows. On the other hand, social housing has positive effects on individual adjustments to the environment through social facilitation or learning (Creel and Albright 1988; Boissy and Le Neindre 1990; Bouissou et al 1994; De Paula Vieira et al 2012; Meagher et al 2015; Costa et al 2016). The study of Webb et al (2015) suggests that also temperament may affect learning an operant conditioning task in cows.

\subsection{Trial 2}

The average of the square crossings in all tests was tended to be highest in the $\mathrm{H}$ group and the lowest in MA. However, the differences were small. The lower level of ambulating behaviour may reflect a hider strategy in the responses of cows to novel environments (Veissier et al 1998). All farm animals are strongly motivated to explore and investigate when they encounter a new environment. Only when the environment has become very familiar to them does the exploratory behaviour is less pronounced, but it reappears after any change in its environment (Fraser and Broom 1997). The effect of novelty on the locomotor play is expressed by the exploratory behaviour (Rushen and Passillé de 2014).

Housing effects may modify cattle exploratory behaviour and can affect the motivation to perform locomotion in an arena test (Jensen 1999; Sutherland et al 2014). In particular, separation from the dam and the level of confinement change the constitution of locomotor behaviour patterns (Albright and Arave 1997). At the present study, the result is in agreement with the finding of more authors (Dellmeier et al 1985; Purcell and Arave 1991; Veissier and Neindre 1992; Jensen et al 1997; Broom and Fraser 2007;
Passille and Rushen 1996; Sisto and Friend 2001; Jensen et al 2004). Cows from individual housing showed more open-field activity than cows reared in group housing. According to Warnick et al (1977); De Paula Vieira et al (2012) and Fujiwara et al (2014), calves with early social contacts show less fear in response to novelty in comparison to calves reared in isolation. Early social experience influences cattle behaviour until adulthood (Albright and Arave 1997; Hemsworth et al 1996).

Contact behaviours to the unfamiliar person (especially frequencies or lengths of staying in the square) were tended to be highest in $\mathrm{H}$ and $\mathrm{MH}$ groups and the lowest in MN. This could be due to the presence of a caregiver when feeding the calves in the hutches. We can put it in the category of early experience. The least used to humans were dairy cows MN. And that explains their little relationship to an unfamiliar man. As was proved in the evaluation of the behaviour of heifers from various rearing systems in open field tests (Broucek et al 2000), the animals raised by foster cows had the worst relationship to unfamiliar humans in comparison to heifers from other rearing systems.

However, the differences among treatment groups were insignificant. The cows may have been habituated in the last test, so they did not respond strongly enough to stimuli. Cattle usually become less fearful, as this is associated with habituation, with the animal becoming more familiar with handling procedures and the environment (Kilgour 1975; Houpt 1991; Doyle and Moran 2015). These approach responses can be usefully considered as the level of fear of humans (Munksgaard and Jensen 1996; Passilé et al 1995; Jensen et al 1999). Although the animals may be motivated to both avoid and explore the arena, the fear of humans will have a major influence on the animal's approach to the human stimulus (Hemsworth and Coleman 1998).

The artificial rearing of calves ( $\mathrm{H}, \mathrm{HA}$ groups) may be one of the most important experiences of a dairy animal in shaping its subsequent responses to humans (Albright and Arave 1997). Boissy and Bouissou (1988) reported that dairy heifers handled from birth to 9 months showed less avoidance of humans than those that had received less human contact. Dairy cattle are regularly in close contact with humans, thus becoming a significant aspect of their environment (Munksgaard et al 2001; Wechsler and Lea 2007). Group $\mathrm{MN}$ is an exception.

\subsection{Trial 3}

This part of the study aimed to compare the reaction of dairy cows in the first lactation on positive and negative artificially caused stimuli. Cows received three treatments: gentle handling, and aversive handling using noise and electrical shock.

Handling studies with dairy cows have shown that negative tactile interactions from handlers will increase their fear of humans. So, the behavioural responses of cattle to humans may be regulated by the nature of the experiences occurring around the time of interactions with humans 
(Breuer et al 2000; Hemsworth and Coleman 1998; Appleby and Hughes 1997; Leaver 1999).

Group $\mathrm{H}$ showed the longest time to cross the AT, the fastest were dairy cows from groups $\mathrm{MH}$ and MA. Also, animals from groups $H A$ and $H$ turned the most in the $A T$, the least from groups $\mathrm{MH}$ and $\mathrm{MA}$. We can see that the cows that were kept with their mother in the first seven days of life are different from the cows that were separated from the mother after 24 hours of life. These groups (MA, MH) probably adapted better to a new and unfamiliar environment than animals reared without a mother, which may mean that they can cope more easily with a negative situation. They have to go through anyway; they were not so afraid. Cattle are naturally shy and tend to react slowly (Grandin and Deesing 2014; Albright and Arave 1997). Rearing with dams shows indications of reduced fearfulness (Le Neindre 1989; Wagner et al 2012, 2015).

The reluctance of cows to cross AT can be caused by a conflict between approach versus avoidance. It occurs in the zone where both motivations begin to act and come into balance. It manifests in the typical behaviour of the animal: cow stops, with its movements it indicates the indecision between locomotion forwards and backwards (Albright and Arave 1997).

At the present work, animals reared without mother (group $\mathrm{H}$ and $\mathrm{HA}$ ) may be able to anticipate negative treatment at the end of the aversive alley and refuse to pass through the alley. It has been observed that calves from a single pen system have a greater tendency to approach a novel stimulus than calves from a group-housing system as noticed Fraser and Broom (1997).

Generally, after a positive treatment on the first day all cows needed more time to cross the AT on the second (noise) and third (electric prod) day as a result of the aversion treatment. If the treatment is aversive, the animals spend more time and required more force to reach the end of the AT than with positive treatment (Pajor et al 2000).

Animals in groups $\mathrm{HA}$ and $\mathrm{H}$ stood the most in the AT. Also, the highest number of sections in which the animals stood for more than three seconds was found in groups $\mathrm{HA}$ and $\mathrm{H}$, the dairy cows from groups $\mathrm{MH}$ and $\mathrm{MA}$ stood the least. Cows of $\mathrm{H}$ group stood the longest time in the 7th section, the shortest time was recorded for the whole trial in the MA and $\mathrm{MH}$ groups. It is possible that group $\mathrm{H}$ and $\mathrm{HA}$ had a greater stress response and therefore, the dairy cows remained standing in some section. The social deprivation in the first week of life could affect the behaviour of heifers in the long run and cause an abnormality of behavioural development (Broom and Fraser 2007; Juhas et al 2001).

Similarly, $\mathrm{HA}$ and $\mathrm{H}$ groups returned towards the start the most, the least returns were shown by group MN. At the time of the first return, significant differences among the groups were found. The cows of $\mathrm{MA}, \mathrm{MH}$, and $\mathrm{MN}$ groups returned the fastest. The results were affected by time separation from the mother (4th and 7th day of life), opposite to the $2^{\text {nd }}$ day of $\mathrm{HA}$ and $\mathrm{H}$ groups.
Cows of MN group vocalized the most. They did not want to adapt and expressed stress in line with recent research (Boissy and Le Neindre 1997; Watts and Stookey 2000; Flower and Weary 2001). Vocal behaviour reflected an unpleasant treatment or separation (Watts and Stookey 2001; Stehulova et al 2008; Rhim 2013; Johnsen et al 2015; Green et al 2018).

Aversive handling can result in a generalized fear of people, but this fear can be overcome by positive handling (Hemsworth et al 1995; Passille et al 1996). Non-aggressive forms of tactile contact between humans and animals (brushing) have often been reported to decrease fear of humans and make handling easier in cattle (Boissy and Bouissou 1988; Boivin et al 1992; Jago et al 1999; Munksgaard et al 1997). At the present study, the positive treatment through brushing was applied only on the first day. The animals of the $\mathrm{MH}$ group were brushed the most, the cows of the MN group the least. The reluctance to brushing in the MN group can be explained by the lack of handling during the milk feeding period and the consequent fear of people. Similarly, Boivin et al (1992) found that calves handled for short periods during rearing were easier to handle in a number of handling tests at a later age than calves that were not handled. It may depend on rearing in the first week of life. Early handling of cattle can reduce their fear of humans (Boivin et al 1992; Boivin et al 1994).

Ease of handling of the animals is an important factor for the safety of the farmer and the welfare of the animals. It would have influenced by previous experience and depends on excitability, fear, and state of motivation (Rushen et al 1998; Hemsworth and Coleman 1998). Fear of dairy cattle can alter their behavioural responses to unknown environment stimuli (Passille et al 1996; Von Keyserlingk et al 2009; Mackay et al 2014).

A possible explanation for this evident fearfulness is then perhaps the experience of stress response from separation (Hemsworth et al 1995). Fear of humans is a source of dairy cow stress and may be the result of aversive animal care (Pajor et al 2000, 2003; Munksgaard et al 1997). However, according to (Burrow 1997; Juhas and Strapak 2013) it depends mainly on temperament. Cattle usually improve their temperament and become less fearful with age, as this is associated with habituation, with the animal becoming more familiar with handling procedures and the environment (Broom and Fraser 2007; Doyle and Moran, 2015).

\section{Conclusions}

Dairy cattle need to develop behavioural flexibility to successfully cope with the stressors. The study of humananimal interactions is of importance to dairy husbandry as the fear of animals to people can make them difficult to handle and welfare and production can be affected. The present study can answer some questions about the role of learning and aversion abilities in dairy cattle.

Cows reared by drinking automate feeder controlled by computer appear to be the most adaptable at the maze, 
and cows reared by nursing cows showed the worse orientation in unfamiliar space and were the least adaptable. Contact behaviours of unfamiliar man tended to be highest in cows reared in hutches and the lowest in cows kept with a nursing cows.

Animals housed with their mother during early rearing were quieter and had a faster rate of time to cross the aversion alley. Also they showed less aversive behaviour than animals separated from the mother 24 hours after birth.

The results show that the method used to rear heifers may have a significant impact on their maze and aversive behaviour after calving, their raising during milk feeding period has a significant impact on their behaviour in adulthood. However, the rearing conditions had a little longterm effect on the open-field behaviour.

\section{Conflict of Interest}

The authors declare that they have no conflict of interest.

\section{Funding}

This article was written based on data project APVV-15-0060 of the SRDA, Slovakia, and Sustainable smart farming systems taking into account the future challenges 313011W112, supported by the Operational Programme Integrated Infrastructure and the European Regional Development Fund.

\section{References}

Albright JL, Arave CW (1997) The Behaviour of Cattle. CAB International. Appleby MC, Hughes BO (1997) Animal Welfare. CAB International.

Arave CW, Mickelsen CH, Walters JL (1985) Effect of early rearing experience on subsequent behavior and production of Holstein heifers. Journal of Dairy Science 68: 923-929.

Arave CW, Lamb RC, Arambel MJ, Purcell D, Walters JL (1992a) Behaviour and maze learning ability of dairy calves as influenced by housing, sex and sire. Applied Animal Behaviour Science 33:149-163

Arave CW, Albright JL, Armstrong DV, Foster WW, Larson LL (1992b) Effects of isolation of calves on growth, behavior, and first lactation milk yield of holstein cows. Journal of Dairy Science 75:3408-3415.

Arave CW (1996) Assessing sensory capacity of animals using operant technology. Journal of Animal Science 74:1996-2009.

Blackshaw JK (1996) Developments in the study of human-animal relationships. Applied Animal Behaviour Science 47:1-6.

Boissy A (1995) Fear and fearfulness in animals. The Quarterly Review of Biology 70:165-191.

Boissy A, Bouissou MF (1988) Effects of early handling on heifers subsequent reactivity to humans and to unfamiliar situations. Applied Animal Behaviour Science 20:259-273.

Boissy A, Bouissou MF (1995) Assessment of individual differences in behavioural reactions of heifers exposed to various fear-eliciting situations. Applied Animal Behaviour Science 46:17-31.

Boissy A, Le Neindre P (1997) Behavioral, cardiac and cortisol responses to brief peer separation and reunion in cattle. Physiology \& Behavior 61:693699.

Bouissou MF, Boissy A, Le Neindre P, Veissier I (2001) The social behaviour of cattle. in: Keeling L, Gonyou HW (eds) Social Behaviour in Farm Animals. CAB International, Wallingford, UK, pp 113-145.
Boissy A, Le Neindre P (1990) Social influences on the reactivity of heifers: Implications for learning abilities in operant conditioning. Applied Animal Behaviour Science 25:149-165.

Boivin X, Le Neindre P, Chupin JM (1992) Establishment of cattle-human relationships. Applied Animal Behaviour Science 32:325-335.

Boivin X, Le Neindre P, Chupin JM, Garel JP, Trillat G (1992) Influence of breed and early management on ease of handling and open-field behaviour of cattle. Applied Animal Behaviour Science 32:313-323.

Boivin X, Le Neindre P, Garel JP, Chupin JM (1994) Influence of breed and rearing management on cattle reactions during human handling. Applied Animal Behaviour Science 39:115-122.

Breuer K, Hemsworth PH, Barnett JL, Matthews LR, Coleman GJ (2000) Behavioural response to humans and the productivity of commercial dairy cows. Applied Animal Behaviour Science 66:273-288.

Broom DM, Fraser AF (2007) Domestic Animal Behaviour and Welfare. CAB International.

Broucek J, Uhrincat M, Friend TH, Arave CW, Hanus A, Kisac P (2000) Effects of rearing methods of calves prior to weaning on subsequent open-field behaviour at 28 weeks of age. Journal of Animal Science 78 (Suppl 1)/Journal of Dairy Science 83 (Suppl 1):35.

Broucek J, Arave C., Friend TH, Uhrincat M, Mihina S, Kisac P, Hanus A (2002) Effects of rearing from the second week to weaning on heifers behavior in maze learning ability tests. Proceedings, Western Section, American Society of Animal Science, 53:93-96.

Burrow HM (1997) Measurements of temperament and their relationships with performance traits of beef cattle. Animal Breeding Abstracts 65:477495.

Costa JHC, von Keyserlingk MAG, Weary DM (2016) Effects of group housing of dairy calves on behavior, cognition, performance, and health. Journal of Dairy Science 99:2453-2467.

Creel SR, Albright JL (1988) The effects of neonatal social isolation on the behavior and endocrine function of holstein calves. Applied Animal Behaviour Science 21:293-306.

Dellemeier GR, Friend TH, Gbur EE (1985) Comparison of four methods of calf confinement. II. Behaviour. Journal of Animal Science 60:1102-1109.

Doyle R, Moran J (2015) Cow Talk: Understanding Dairy Cow Behaviour to Improve Their Welfare on Asian Farms. Csiro Publishing, Australia.

Flower FC, Weary DM (2001) Effects of early separation on the dairy cow and calf: 2. separation at 1 day and 2 weeks after birth. Applied Animal Behaviour Science 70:275-284.

Fraser AF, Broom DM (1997) Farm animal behaviour and welfare. CAB International.

Fujiwara M, Rushen J, Passillé de AM (2014) Dairy calves' adaptation to group housing withautomated feeders. Applied Animal Behaviour Science 158:17.

Grandin T. (2019) Livestock Handling and Transport. CAB International.

Grandin T, Deesing MJ (2014) Genetics and Behavior During Handling, Restraint, and Herding. In: Grandin T (ed) Genetics and the Behavior of Domestic Animals, 2nd edn. Academic Press, San Diego, pp 115-158.

Green AC, Johnston IN, Clark CEF (2018) Invited review: The evolution of cattle bioacoustics and application for advanced dairy systems. Animal 12:1250-1259.

Hart BL (1985) Early experience and behaviour. In: Hart BL (ed) The behaviour of domestic animals. W.H. Freeman and Co., New York, pp 242-262.

Hemsworth PH, Barnett JL (1987) Human-Animal Interactions. Veterinary Clinics of North America, Food Animal Practice 2:339-356.

Hemsworth PH, Barnett JL, Beveridge L (1995) The welfare of extensively managed dairy cattle: A review. Applied Animal Behaviour Science 42:161182.

Hemsworth PH, Price E.O, Borgwardt R (1996) Behavioural responses of domestic pigs and cattle to humans and novel stimuli. Applied Animal Behaviour Science 50:43-56. 
Hemsworth PH, Coleman GJ (1998) Human-Livestock Interactions. The Stockperson and the Productivity and Welfare of Intensively Farmed Animals. CAB International.

Hemsworth P (2003) Human-animal interactions in livestock production. Applied Animal Behaviour Science 81:185-198.

Houpt KA (1991) Domestic Animal Behavior for veterinarians and animal scientists. lowa State University Press, Ames.

Jago JG, Krohn CC, Matthews LR (1999) The influence of feeding and handling on the development of the human-animal interactions in young cattle. Applied Animal Behaviour Science 62:137-151.

Jensen MB (1999) Effects of confinement on rebounds of locomotor behaviour of calves and heifers, and the spatial preferences of calves. Applied Animal Behaviour Science 62:43-56.

Jensen MB, Vestergaard KS, Krohn ChC, Munksgaard L (1997) Effect of single versus group housing and space allowance on responses of calves during open-field tests. Applied Animal Behaviour Science 54:109-121.

Jensen MB, Munksgaard L, Mogensen L, Krohn CC (1999) Effect of housing in different social environments on open-field and social responses of female dairy calves. Acta Agriculturae Scandinavica, Section A, Animal Science 49:113-120.

Jensen MB, Tuomisto L, Pedersen LJ (2004) Locomotor behaviour in dairy calves, the use of demand functions to assess the effect of deprivation. Applied Animal Behaviour Science 86:3-14.

Johnsen JF, Passillé de AM, Mejdell CM, Boe KE, Grondahl AM, Beaver A, Rushen J, Weary DM (2015) The effect of nursing on the cow-calf bond. Applied Animal Behaviour Science 163:50-57.

Jones RB (1997) Fear and distress. In: Appleby MC, Hughes BO (eds) Animal welfare. CAB International, pp.75-87.

Juhas P, Debreceni O, Vavrisinova K, Bulla J, Strapak P (2001) Abnormal Behaviours in Cattle in Slovakia. Biotechnology in Animal Husbandry 17:113118.

Juhas P, Strapak P (2013) The temperament estimation in the dairy cattle. In Book of abstracts of the 64th Annual Meeting of the European Federation of Animal Science, Wageningen Academic Publishers, 26.-30.August 2013, Nantes, 19:341.

Kilgour RJ (1975) The open-field test as an assessment of the temperament of dairy cows. Animal Behaviour 23:615-624.

Kilgour R (1981) Use of the Hebb-Williams closed-field test to study the learning ability of Jersey cows. Animal Behaviour 29:850-860.

Kilgour R, Foster TM, Temple W, Matthews LR, Bremner KJ (1991) Operant technology applied to solving farm animal problems. An assessment. Applied Animal Behaviour Science 30:141-166.

Lauber MC, Hemsworth PH, Barnett JL (2009) The effect of breed, time spent with dam and late pregnancy induction of parturition on behavioural development in dairy calves. Behavioural Processes 82:301-311.

Le Neindre P (1989) Influence of rearing conditions and breed on socia behaviour and activity of cattle in novel environments. Applied Animal Behaviour Science 23:129-140.

Leaver JD (1999) Dairy Cattle. In: Ewbank R, Kim-Madslien F, Hart CB (eds) Management and Welfare of Farm Animals. UFAW Farm Handbook, Universities Federation for Animal welfare, pp 17-47.

MacKay JRD, Haskell MJ, Deag JM, van Reenen K (2014) Fear responses to novelty in testing environments are related to day-to-day activity in the home environment in dairy cattle. Applied Animal Behaviour Science 152:716.

Mala G, Novak P, Jiroutova P, Knizek J, Prochazka D, Slavikova M (2019) The effect of housing system on behaviour of dairy calves. Proceedings of the XIXth Congress International Society of Animal Hygiene, Wroclaw, Poland, pp 46-48.

Meagher RK, Daros RR, Costa JHC, von Keyserlingk MAG, Hötzel MJ, Weary DM (2015) Effects of Degree and Timing of Social Housing on Reversal Learning and Response to Novel Objects in Dairy Calves. PLoS ONE 10: e0132828. doi: 10.1371/journal.pone.0132828
Mogensen L, Krohn CC, Foldager J (2010) Long-term Effect of Housing Method during the First Three Months of Life on Human-Animal Relationship in Female Dairy Cattle. Acta Agriculturae Scandinavica, Section A - Animal Science 49:163-171.

Munksgaard L, Jensen MB (1996) The use of "open field" tests in the assessment of welfare of cattle. Acta Agriculturae Scandinavica, Section A Animal Science (Suppl) 27:82-85.

Munksgaard L, Passillé AM, Rushen J, ThodbergK., Jensen MB (1997) Discrimination of People by Dairy Cows Based on Handling. Journal of Dairy Science 80:1106-1112.

Munksgaard L, Passillé de AM, Rushen J, Herskin MS, Kristensen AM (2001) Dairy cows' fear of people: social learning, milk yield and behaviour at milking, Applied Animal Behaviour Science 73:15-26.

Novak P, Vokralova J, Tittl K, Mala G, Illek J (2010) Selected aspects of welfare and prevention of disease in ruminants. Veterinarstvi 60:25-27.

Novak P, Mala G, Jarolimkova A. 2019. Animal, housing and nutrition as prerequisite for health, reproduction and production in dairy cattle. Proceedings of the XIXth Congress International Society of Animal Hygiene, Wroclaw, Poland, pp 49-51.

Pajor EA, Rushen J, Passillé de AMB (2000) Aversion learning techniques to evaluate dairy cattle handling practices. Applied Animal Behaviour Science 69:89-102.

Pajor EA, Rushen J, Passillé de AMB (2003) Dairy cattle's choice of handling treatments in a Y-maze. Applied Animal Behaviour Science 80:93-107.

Passillé de AM, Rushen J, Martin F (1995) Interpreting the behaviour of calves in an open-field test: a factor analysis. Applied Animal Behaviour Science 45:201-213.

Passillé de AM, Rushen, J, Ladewig J, Petherick C (1996) Dairy calves discrimination of people based on previous handling. Journal of Animal Science 74:969-974.

Passillé de AM, Rushen J (2006) Calves' behaviour during nursing is affected by feeding motivation and milk availability. Applied Animal Behaviour Science 101:264-275.

Paula Vieira de A, Passillé de AM, Weary DM (2012) Effects of the early social environment on behavioral responses of dairy calves to novel events. Journal of Dairy Science 95:5149-5155.

Petrikovic P, Sommer A (2002) Requirement of Nutrients for Cattle. 2nd Edition. Publication of VUZV, Nitra.

Purcell D, Arave CW (1991) Isolation vs. group rearing in monozygous twin heifer calves. Applied Animal Behaviour Science 31:147-156.

Rhim SJ (2013) Vocalization and behavior of Holstein cows and calves after partial and complete separation. Revista Colombiana de Ciencias Pecuarias 26:24-29.

Rushen J (1986) The Validity of Behavioural Measures of Aversion: a Review. Applied Animal Behaviour Science 16:309-323.

Rushen J, Passillé de AM (1998) Behaviour, welfare and productivity of dairy cattle. Canadian Journal of Animal Science 78 (Suppl):3-21.

Rushen J, Passillé de AMB (2014) Locomotor play of veal calves in an arena: Are effects of feed level and spatial restriction mediated by responses to novelty? Applied Animal Behaviour Science 155:34-41.

Sisto AM, Friend TH (2001) The effect of confinement on motivation to exercise in young dairy calves. Applied Animal Behaviour Science 73:83-91.

Slavik P, Illek J, Brix M, Musilova L, Rajmon R, Klabanova P, Jilek F (2009) Health Status of Beef Cows and their Calves in the Czech Republic. Acta Veterinaria Brno 78:47-56.

Stehulova I, Lidfors L, Spinka M (2008) Response of dairy cows and calves to early separation: effect of calf age and visual and auditory contact after separation. Applied Animal Behaviour Science 110:144-165.

Stewart PH, Arave CW, Dias B (1992) The effect of observation on Holstein heifer's learning ability in a closed field maze. Journal of Animal Science 70 (Suppl 1): 155. 
Sutherland MA, Worth GM, Schütz KE, Stewart M (2014) Rearing substrate and space allowance influences locomotor play behaviour of dairy calves in an arena test. Applied Animal Behaviour Science 154:8-14.

Veissier I, Le Neindre P (1992) Reactivity of Aubrac heifers exposed to a novel environment alone or in groups of four. Applied Animal Behaviour Science 33:11-15.

Veissier I (1993) Observational learning in cattle. Applied Animal Behaviour Science 35:235-243.

Veissier I, Boissy A, Nowak R, Orgeur P, Poindron P (1998) Ontogeny of social awareness in domestic herbivores. Applied Animal Behaviour Science 57:233-245.

Von Keyserlingk MAG, Rushen J, de Passillé AM, Weary DM (2009) Invited review: the welfare of dairy cattle-key concepts and the role of science. Journal of Dairy Science 92:4101-4111.

Wagner K, Seitner D, Barth K, Palme R, Futschik A, Waiblinger S (2012) Integration into the dairy cow herd: Long-term effects of mother contact during the first twelve weeks of life. Applied Animal Behaviour Science 141:117-129.
Wagner K, Seitner D, Barth K, Palme R, Futschik A, Waiblinger S (2015) Effects of mother versus artificial rearing during the first 12 weeks of life on challenge responses of dairy cows. Applied Animal Behaviour Science 164:111.

Warnick VD, Arave CW, Mickelsen CH (1977) Effects of group, individual and isolated rearing of calves on weight gain and behavior. Journal of Dairy Science 60:947-953.

Watts JM, Stookey JM (2000) Vocal behaviour in cattle: the animal's commentary on its biological processes and welfare. Applied Animal Behaviour Science 67:15-33.

Watts JM, Stookey JM (2001) The propensity of cattle to vocalise during handling and isolation is affected by phenotype. Applied Animal Behaviour Science 74:81-95.

Webb LE, van Reenen CG, Jensen MB, Schmitt O, Bokkers EAM (2015) Does temperament affect learning in calves? Applied Animal Behaviour Science 165:33-39.

Wechsler B, Lea SEG (2007) Adaptation by learning: Its significance for farm animal husbandry. Applied Animal Behaviour Science 108:197-214. 